\title{
Peranan Intellectual Capital sebagai Mediasi antara Corporate Social Responsibility dan Kinerja Perusahaan Perbankan
}

\author{
Fivi Anggraini ${ }^{1}$, Daniati Puttri ${ }^{2}$, Wina Septriani ${ }^{3}$, Zefriyenni ${ }^{4}$ \\ ${ }^{123}$ Fakultas Ekonomi dan Bisnis, Universitas Bung Hatta Padang, Indonesia \\ ${ }^{4}$ Universitas Putra Indonesia YPTK Padang, Indonesia \\ E-mail:fivianggraini@bunghatta.ac.id
}

\begin{abstract}
Corporate social responsibility activity is a strategy that contributes to the improvement of company performance in the long run. Investment on intellectual capital development has a close relationship with stakeholders through corporate social responsibility activities that eventually affect company performance. This study aims to examine the role of intellectual capital as a mediator between corporate social responsibility and banking company performance. The samples for this study were 20 bank companies that were listed on the Indonesia Stock Exchange (IDX) in year 2014-2018. The findings have proved empirically that intellectual capital as a mediating variable has a significant effect on the relationship between corporate social responsibility and performance of bank companies. Therefore, bank companies are expected to invest more intangible assets or intellectual capital and deliver their corporate social responsibility activities. As an implication of this study, the bank companies must carry out activities that provide added and unique values from their corporate social responsibility programs because the programs are the company's responsibility to fulfil the applicable regulations, community and their environment.
\end{abstract}

Keywords: corporate social responsibility, intellectual capital, bank company performance

\section{Pendahuluan}

Perusahaan perbankan sebagai salah satu lembaga keuangan, perlu menjaga kinerjanya agar dapat beroperasi secara optimal. Di Indonesia perbankkan memiliki peranan penting bagi pertumbuhan perekonomian negara antara lain sebagai perantara keuangan dan pihak-pihak yang memiliki dana dan pihak yang kekurangan dana serta memperlancar lalu lintas pembayaran. Bank dalam menjalankan operasinya tentunya tak lepas dari berbagai macam risiko diantaranya resiko kredit. Menurut [1] risiko kredit adalah risiko kemungkinan terjadinya kerugian bank sebagai akibat dari tidak dilunasinya kembali kredit yang diberikan bank kepada debitur. Salah satu rasio keuangan yang berkaitan dengan risiko kredit adalah non performing loan (NPL). Non performing loan adalah perbandingan antara total kredit bermasalah dengan total kredit yang diberikan kepada debitur. Resiko lain yang mencerminkan resiko organisasi perbankkan adalah resiko pasar. Menurut peraturan Bank Indonesia salah satu proksi dari risiko pasar adalah suku bunga. Suku bunga diukur dari selisih antar suku bunga pendanaan (funding) dengan suku bunga pinjaman (lending). Dilihat dari bentuk absolut adalah selisih antara total biaya bunga pendanaan dengan total biaya bunga pinjaman dimana dalam istilah perbankan disebut net interest margin (NIM) [2]. Dengan demikian besarnya NIM akan mempengaruhi laba-rugi Bank yang pada akhirnya mempengaruhi kinerja bank tersebut. Berdasarakan data Otoritas Jasa Keuangan (OJK) memaparkan bahwa sampai dengan bulan pertama tahun 2018 kinerja perbankan masih membaik. Namun dari sisi NonPerforming Loan (NPL) bermasalah yaitu menurun dibandingkan dengan posisi Januari 
2017. Per akhir Januari 2018, kondisi NPL berada dilevel 2,86\% atau menurun dari 3,09\% diperiode yang sama tahun lalu. Sementara secara net, rasio NPL per Januari terjaga diposisi $1,23 \%$ menurun dari periode tahun lalu 1,35\%. Seiring dengan pertumbuhan kredit Net Interest Margin (NIM) juga ikut mengalami penurunan bila dibandingkan dengan tahun sebelumnya. Per Januari 2018 NIM hanya tumbuh Rp 60,4 trilliun dalam setahun naik $8,36 \%$. Padahal Januari tahun lalu NIM perbankan tumbuh dua digit sebanyak 10,04\%.

Berdasarkan fenomena tersebut salah satu upaya peningkatan kinerja perusahaan menurut [3] adalah dengan menerapkan corporate social responsibility. Kajian mengenai corporate social responsibility semakin berkembang pesat seiring banyak kasus yang terjadi dimana perusahaan tidak memberikan kontribusi positif secara langsung kepada masyarakat bahkan memberikan dampak negatif atas beroperasinya perusahaan. Menurut [4] corporate social responsibility merupakan keterbukaan dalam mengungkapkan aktivitas-aktivitas perusahaan berkaitan dengan kegiatan sosial, terutama yang berkaitan dengan lingkungan hidup. Penerapan corporate social responsibility dapat menumbuhkan rasa percaya perusahaan terhadap masyarakat dan investor khususnya [5]. Alasannya bahwa aktivitas dari corporate social responsibility merupakan keberpihakan perusahaan terhadap masyarakat dilihat dari tidak hanya dari produk namun juga melalui tata kelola perusahaan. Pada saat masyarakat menjadi pelanggan memiliki penilaian positif terhadap perusahaan, maka akan mampu menaikkan citra perusahaan yang direfleksikan melalui kinerja perusahaan yang akan meningkat [4]. Pelaksanaan aktivitas corporate social responsibility telah terbukti berpengaruh terhadapkinerja perusahaan [6].

Investasi pengembangan intellectual capital mempunyaihubungan yang erat dengan stakeholder melalui aktivitas corporate social responsibility [7] dan [8]. Peran intellectual capital sangat dibutuhkan dalam peningkatan kinerja perusahaan untuk menciptakan keunggulan kompetitif. Penelitian yang dilakukan [9] dan [16] telah membuktikan bahwa intellectual capital memiliki pengaruh terhadap kinerja perusahaan. Konsep intellectual capital perusahaan akan mampu menciptakan nilai tambah perusahaan sehingga berdampak terhadap kinerja keuangan yang baik. Dengan demikian, semakin tinggi intellectual capital maka semakin tinggi pendayagunaan sumber daya perusahaan dalam menghasilkan laba dan semakin baik perusahaan dalam mengelola komponen intellectual capital maka akan membawa pengaruh terhadap aset perusahaan [15]. Penelitian ini penting dilakukan karena belum ada penelitian komprehensif yang menguji intellectual capital sebagai variabel mediasi hubungan antara corporate social responsibility terhadap kinerja pada perusahaan perbankan. Penelitian ini diharapkan dapat membuktikan bahwa intellectual capital sebagai salah satu faktor yang berpengaruh terhadap peningkatan kinerja perusahaan pada perusahaan perbankkan.

\section{Pengaruh corporate social responsibility terhadap kinerja perusahaan perbankan}

Corporate social responsibility merupakan klaim agar perusahaan tidak hanya beroperasi untuk kepentingan para pemegang saham (shareholder), tetapi juga terhadap pihak stakeholder [9]. Aktivitas corporate social responsibility menjadi suatu strategi perusahaan yang memberikan kontribusi keuntungan peningkatan kinerja perusahaan jangka panjang [3], [5], dan [18].

$\mathrm{H}_{1}$ : Corporate social responsibilty berpengaruh terhadap kinerja perusahaan perbankan. 


\section{Pengaruh corporate social responsibility terhadap intellectual capital}

Intellectual capital sebagai sumber daya berbasis pengetahuan meliputi tiga komponen utama yang saling berhubungan yaitu: human capital, structural capital dan relational capital merupakan suatu hal yang penting yang dapat mempengaruhi kinerja perusahaan [15] dan [16]. Menurut [18] menyatakan bahwa semakin tinggi biaya corporate social responsibility yang dikeluarkan oleh perusahaan, maka akan semakin menaikkan nilai intelectual capital.

$\mathrm{H}_{2}$ : Corporate social responsibilty berpengaruh terhadap intellectual capital.

\section{Pengaruh Intellectual Capital terhadap Kinerja Perusahaan Perbankan}

Intellectual capital merupakan sekelompok aset pengetahuan yang merupakan atribut organisasi yang berkontribusi signifikan untuk meningkatkan kinerja perusahaan [7], [8], [15] dan [16]. Menurut [11] intellectual capital mempeunyai peran penting dalam peningkatan kinerja perusahaan. Investasi perusahaan dalam intellectual capital yang disajikan dalam laporan keuangan memberikan sinyal kepada investor akan memberikan nilai lebih tinggi pada perusahaan yang memiliki sumber daya intellectual capital dibandingkan dengan perusahaan yang memiliki sumber daya intellectual yang rendah.

$\mathrm{H}_{3}$ : Intellectual capital berpengaruh terhadap kinerja perusahaan perbankan.

\section{Intellectual capital memediasi antara corporate social responsibility dan kinerja perusahaan perbankan}

Menurut konsep global compact initiative (2002) tentang pemahaman corporate social responsibility dengan 3P yaitu profit, people, planet bahwa bisnis tidak hanya sekedar mencari keuntungan (profit) melainkan juga memberikan kesejahteraan kepada orang lain (people) dan menjamin keberlangsungan hidup bumi [20]. Dalam pelaksanaan corporate social responsibility perusahaan akan mengeluarkan biaya yang akan mengurangi profit perusahaan, namun manfaatnya perusahaan memiliki citra yang baik di masyarakat. Semakin baik citra masyarakat, maka semakin tinggi pula loyalitas dari para konsumen sehingga kinerja perusahaan akan meningkat]. Aktivitas corporate social responsibility dengan menggunakan sumber daya berbasis pengetahuan yang dimiliki perusahaan atau disebut intellectual capital akan meningkatkan kinerja perusahaan.

$\mathrm{H}_{4}$ : Corporate social responsibility berpengaruh terhadap kinerja perusahaan perbankan dengan intellectual capital sebagai variabel mediasi.

\section{Tinjauan Literatur}

\subsection{Populasi dan Sampel}

Populasi dalam penelitian ini adalah seluruh perusahaan sektor Perbankan yang terdaftar di Bursa Efek Indonesia yaitu www.idx.co.id periode 2014-2018. Sampel penelitian ini sebanyak 20 perusahaan perbankkan dari 43 perusahaan yang terdafatr di Bursa Efek Indonesia periode 2014-2018_Penentuan sampel pada penelitian ini adalah dengan menggunakan teknik purposive sampling. 


\section{Definisi operasional dan pengukuran variabel}

Kinerja Perusahan merupakan hasil keputusan individual yang dibuat secara keuangan maupun non keunangan oleh manajemen. Penelitian ini untuk menilai kinerja perusahaan melibatkan analisis dampak keuangan kumulatif dan ekonomi dari keputusan dan mempertimbangkannya dengan menggunakan ukuran komparatif. Dalam penelitian ini rumus yang digunakan untuk mengukur kinerja perusahaan perbankan adalah Net Interest Margin (NIM) danNon performing Loan (NPL).

Net Interest Margin (NIM)adalahperbandingan antara pendapatan bunga bersih terhadap ratarata aktiva produktif. Pendapatan bunga bersih diperoleh dari pendapatan bunga dikurangi beban bunga. Aktiva produktif yang diperhitungkan adalah aktiva produktif yang menghasilkan bunga (interest bearing assets). Adapun pengukurannya dengan menggunakan rumus:

$$
N I M=\frac{\text { Pendapatan Bunga Bersih }}{\text { Rata-rata aktiva produktif }}
$$

Non performing loan (NPL) merupakan merupakan rasio keuangan yang menunjukkan resiko kredit yang di hadapi bank akibat pemberian kredit dan investasi dana bank pada fortofolio yang berbeda.. Adapun rasio ini dapat diukur menggunakan rumus:

$$
N P L=\frac{\text { Kredit Bermasalah }}{\text { Total Kredit }} \times 100 \%
$$

Corporate social responsibility merupakan tanggung jawab sosial perusahaan mencangkup citra, promosi, membangun percaya diri, loyalitas karyawan, serta keuntungan dalam konteks lingkungan eksternal, yang berperan untuk memenuhi kebutuhan sosial dan stabilitas ekonomi serta budaya masyarakat. Corporate soocial responsibility diukur dengan proksi CSRI berdasarkan indikator GRI (global reporting initiatives). Metode pengukuran corporate social responsibility (CSR) disclosure mengacu pada pengukuran yang pernah dilakukan oleh [4].

Rumus CSRI adalah sebagai berikut:

$$
\operatorname{CSRIj}=\frac{\sum \times i j}{n j}
$$

Keterangan:

CSRIj : Corporate social responsibility index

nj : jumlah item untuk perusahaan $\mathrm{j}, \leq 91$

$\mathrm{x}_{\mathrm{ij}} \quad$ : dummy variabel: $1=$ jika item I diungkapkan; $0=$ jika item I tidak diungkapkan

Intellectual Capital diartikan sebagai aset tak berwujud yang dapat dimanfaatkan untuk meningkatkan nilai dan daya saing perusahaan. Pada penelitian ini pengukuran komponen intellectual capital (IC) terdiri dari capital employed (CE), human capital (HC), dan structural capital (ST). Intellectual capital dalam penelitian ini diukur dengan Value Added Intellectual Coefficient (VAICTM) yang dikembangkan oleh [28]. Formulasi dan tahapan perhitungan VAICTM adalah sebagai berikut: 
1. Menghitung Value Added (VA)

Nilai tambah (value added) adalah perbedaan antara penjualan (OUT) dan input (IN). Rumus untuk menghitung VA yaitu:

$$
\mathrm{VA}=\mathrm{OUT}-\mathrm{IN}
$$

Keterangan:

Output $($ OUT $)=$ Total penjualan dan pendapatan lain.

Input (IN) = Beban dan biaya-biaya (selain beban karyawan)

2. Menghitung Value Added Capital Employed (VACA)

VACA merupakan indikator efisiensi nilai tambah (Value Added) modal yang digunakan. Rumus untuk menghitung VACA yaitu:

$$
\mathrm{VACA}=\frac{\mathrm{VA}}{\mathrm{CE}}
$$

Keterangan:

VACA = Value Added Capital Employed

$\mathrm{VA} \quad=$ Value Added

$\mathrm{CE} \quad=$ Dana yang tersedia (ekuitas, laba bersih)

3. Menghitung Value Added Human Capital (VAHU)

Value Added Human Capital (VAHU) merupakan indikator efisiensi nilai tambah modal manusia. Rumus untuk menghitung VAHU yaitu:

$$
\mathrm{VAHU}=\frac{\mathrm{VA}}{\mathrm{HC}}
$$

Keterangan:

VAHU = Value Added Human Capital

$\mathrm{VA}=$ Value Added

$\mathrm{HC}=$ Beban tenaga kerja (total gaji, upah dan pendapatan karyawan).

4. Menghitung Structural Capital Value Added (STVA)

Structural Capital Value Added (STVA) merupakan indikator efisiensi nilai tambah modal struktural. Rumus untuk menghitung STVA yaitu:

$$
\text { STVA }=\frac{S C}{V A}
$$

Keterangan:

STVA = Structural Capital Value Added

$\mathrm{VA} \quad=$ Value Added

Structural Capital $(\mathrm{SC})=\mathrm{VA}-\mathrm{HC}$ 
5. Menghitung Value Added Intellectual Coefficient (VAICTM)

VAICTM merupakan penjumlahan dari VACA, VAHU dan STVA. VAICTM dapat juga dianggap sebagai BPI (Business Performance Indicator). VAICTM dihitung dengan rumus sebagai berikut:

$$
\mathrm{VAIC}^{\mathrm{TM}}=\mathrm{VACA}+\mathrm{VAHU}+\mathrm{STVA}
$$

\section{Metodologi Penelitian}

Teknik analisis data yang digunakan dalam penelitian ini menggunakan metode Partial Least Square (PLS) alasannya bahwa dalam penelitian ini terdapat variabel laten yang dibentuk dengan indikator formative dan bukan reflektif. Selain itu alasan lainnya adalah jumlah sampel yang yang relatif kecil, 20 perusahaan yang diteliti setiap tahunnya.

\section{Hasil dan Pembahasan}

Secara umum proses pengumpulan sampel penelitian terdapat sebanyak 43 perusahaan, ada 5 perusahaan tidak menyajikan annula report yang lengkap berturut-turut dan 18 perusahaan yang memiliki laporan keuangan yang tidak lengkap. Dengan demikian jumlah perusahaan perbankan yang diteliti sebanyak 20 perusahaan.

\subsection{Analisis Data}

\section{Evaluasi Model Pengukuran}

Evaluasi model pengukuran adalah evaluasi hubungan antara konstruk dengan indikatornya. Evaluasi ini melalui dua tahap yaitu evaluasi terhadap convergent validity dilihat berdasarkan loading factor untuk masing -masing konstruk dan diskriminant validity untuk melihat output composite reability atau cronbach alpa. Berikut tampilan output Smart PLS pada Gambar 1.

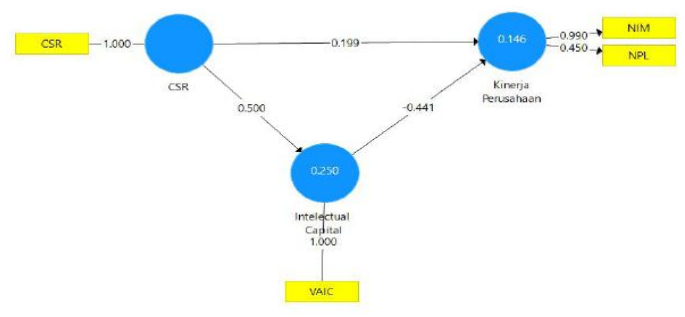

Gambar 1: Output Smart PLS

Diagram jalur diatas menunjukkan bahwa semua indikator memiliki loading factor 1.000 yang berarti bahwa semua indikator sudah valid karena loading factor memenuhi kriteria diatas 0.70 (lihat tabel 1).

Tabel 1: Hasil Pengujian Loading Factor

\begin{tabular}{ccccr}
\hline Indikator & $\begin{array}{c}\text { Corporate } \\
\text { Social } \\
\text { Responsibility }\end{array}$ & $\begin{array}{c}\text { Kinerja } \\
\text { Perusahaan }\end{array}$ & Kriteria & Hasil \\
\hline CSR (Corporate Social Responsibility) & 1,000 & 0,70 & Valid \\
\end{tabular}




\begin{tabular}{llll} 
NIM (Net Interest Margin) & 0,990 & 0,70 & Valid \\
NPL (Non-Performing Loan) & 0,890 & 0,70 & Valid \\
VAIC (Intellectual Capital) & 0,990 & 0,70 & Valid \\
\hline
\end{tabular}

Sumber: Hasil Pengolahan Data dan Program smart PLS

Tabel 2: Hasil Construct Reliability

\begin{tabular}{lccc}
\hline \multicolumn{1}{c}{ Indikator } & $\begin{array}{c}\text { Cronbach's } \\
\text { Alpha }\end{array}$ & $\begin{array}{c}\text { Composive } \\
\text { Reliability }\end{array}$ & $\begin{array}{c}\text { Average Variance } \\
\text { Extracted (AVE) }\end{array}$ \\
\hline CorporateSocial Responsibility & 0,842 & 0,883 & 0,758 \\
Intellectual Capital & 0,794 & 0,879 & 0,709 \\
Kinerja Perusahaan & 0,726 & 0,846 & 0,748 \\
\hline
\end{tabular}

Sumber: Hasil Pengolahan Data dan Program smart PLS

Berdasarkan tabel 2 menunjukkan bahwa nilai cronbach's alpha dan composite reliability diatas 0.7 bernilai tinggi berarti pengukuran masing-masing konstruk berkorelasi tinggi. Selanjutnya hasil pengujian diskriminant validity meliputi cross loading dan membandingkan dengan akar AVE dengan korelasi antar konstruk. Berikut hasil cross loading:

Tabel 3: Cross Loading

\begin{tabular}{lccc}
\hline \multicolumn{1}{c}{ Indikator } & $\begin{array}{c}\text { Corporate Social } \\
\text { Responsibility }\end{array}$ & $\begin{array}{c}\text { Intellectual } \\
\text { Capital }\end{array}$ & $\begin{array}{c}\text { Kinerja } \\
\text { Perusahaan }\end{array}$ \\
\hline Corporate Social Responsibilty & 1,000 & 0,500 & 0,042 \\
Intellectual Capital & 0,500 & $-0,431$ & 0,149 \\
NIM (net interest margin) & 0,990 & 0,990 & 1,000 \\
NPL (nonperforming loan) & 0,890 & 0,890 & 0,990 \\
\hline
\end{tabular}

Sumber: Hasil Pengolahan Data dan Program smart PLS

Hasil cross loading semua indikator berkorelasi tinggi dengan masing-masing konstruknya. Begitu juga, hasil pengujian diskriminat validity lihat Tabel 3 telah berada diatas 0,70 dinyatakan tingkat ketepatan item pendukung masing-masing variabel relatif kuat.

Tabel 4: Discriminant Validity

\begin{tabular}{lccc}
\hline \multicolumn{1}{c}{ Indikator } & $\begin{array}{c}\text { Corporate Social } \\
\text { Responsibility }\end{array}$ & $\begin{array}{c}\text { Intellectual } \\
\text { Capitial }\end{array}$ & $\begin{array}{c}\text { Kinerja } \\
\text { Perusahaan }\end{array}$ \\
\hline Corporate Social Responsibility & 1,000 & & \\
Intellectual Capital & 0,500 & 1,000 & \\
Kinerja Perusahaan & $-0,021$ & $-0,341$ & 0,769 \\
\hline
\end{tabular}

Sumber: Hasil Pengolahan Data dan Program smart PLS

\section{Evaluasi Model Struktural}

Nilai R square dan Q square hasil penelitian ini dapat lihat pada Tabel 6 sebagai berikut:

Tabel 5: Hasil R Square

\begin{tabular}{lccc}
\hline \multicolumn{1}{c}{ Variabel } & R Squere & Q-square & Kesimpulan \\
\hline Intellectual Capital & 0,250 & 0,242 & Lemah \\
Kinerja Perusahaan & 0,146 & 0,129 & Lemah \\
\hline
\end{tabular}

Sumber: Hasil uji R square dan Q square

Berdasarkan tabel 6 pengujian $\mathrm{Q}^{2}$ diperoleh nilai koefisien sebesar 0,129. dengan demikian dapat disimpulkan bahwa kontribusi keseluruhan gabungan variabel independen yang terdiri 
dari corporate governance dan intellectual capital dalam mendorong terbentuknya kinerja keuangan adalah sebesar $12,90 \%$, kontribusi yang diberikan seluruh variabel tersebut adalah lemah.

\section{Hasil jalur struktural untuk hipotesis}

Hasil dari masing-masing hipotesis dapat dilihat pada Tabel 6 dibawah ini:

Tabel 6 Hasil Pengujian Hipotesis

\begin{tabular}{lcccccc}
\hline Model & $\begin{array}{c}\text { Original } \\
\text { Sample } \\
(\mathbf{O})\end{array}$ & $\begin{array}{c}\text { Sample } \\
\text { Mean } \\
(\mathbf{M})\end{array}$ & $\begin{array}{c}\text { Standard } \\
\text { Deviation } \\
(\text { STDEV) }\end{array}$ & $\begin{array}{c}\text { T Statistics } \\
([\mathbf{O} / \text { STDEV] })\end{array}$ & P-values & $\begin{array}{c}\text { Hasil } \\
\text { hipotesis }\end{array}$ \\
\hline $\mathrm{CSR} \rightarrow \mathrm{KP}$ & 0,199 & 0,215 & 0,092 & 2,152 & 0,000 & H1: Diterima \\
$\mathrm{CSR} \rightarrow \mathrm{IC}$ & 0,500 & 0,495 & 0,093 & 5,369 & 0,000 & H2: Diterima \\
$\mathrm{IC} \rightarrow \mathrm{KP}$ & $-0,441$ & $-0,459$ & 0,071 & 6,244 & 0,000 & H3: Diterima \\
$\mathrm{CSR} \rightarrow \mathrm{IC} \rightarrow \mathrm{KK}$ & $-0,226$ & $-0,230$ & 0,068 & 3,247 & 0,000 & H4:Diterima \\
\hline
\end{tabular}

Sumber: Hasil Pengolahan Data dan Program smart PLS

\subsection{Pembahasan}

\section{Pengaruh corporate social responsibility terhadap kinerja perusahaan perbankan}

Berdasarkan hasil pengujian hipotesis pertama pada Tabel 7 ditemukan bahwa corporate social responsibility berpengaruh signifikan terhadap kinerja perusahaan perbankan di Indonesia. Hasil yang diperoleh pada pengujian hipotesis pertama sama dengan penelitian yang dilakukan oleh [17], [3], dan [5] menemukan bahwa corporate social responsibility berpengaruh positif terhadap kinerja perusahaan. Hal ini berati bahwa perusahaan perbankan bertanggungjawab baik terhadap peraturan yang beraku, masyarat sekitar maupun lingkungan alam.

\section{Pengaruh corporate social responsibility terhadap intellectual capital}

Hasil pengujian hipotesis kedua terbukti secara empiris bahwa corporate social responsibility berpengaruh signifikan terhadap intellectual capital. Hasil penelitian ini mendukung penelitian [8], [7], dan [18] ketika perusahaan perbankan melaksanakan aktivitas corporate social responsibility akan berpengaruh terhadap intellectual capital yang dimiliki oleh sebuah perusahaan perbankan sehingga dapat menciptakan nilai tambah dan keunggulan bersaing jangka panjang. Hasil penelitian bertolak belakang dengan peneltian yang dilakukan oleh [19] menemukan bahwa corporate social responsibility tidak berpengaruh terhadap intellectual capital.

\section{Pengaruh intellectual capital terhadap kinerja perusahaan perbankan}

Hasil pengujian data untuk hipotesis ketiga ditemukan bahwa intellectual capital berpengaruh signifikan terhadap kinerja perusahaan perbankan. Hasil penelitian ini sama dengan penelitian yang dilakukan oleh [9] dan [16] menunjukan bahwa semakin tinggi intellectual capital yang dimiliki maka akan meningkatkan kinerja perusahaan perbankan. 


\section{Pengaruh intellectual capital sebagai mediasi hubungan antara corporate social responsibility dan kinerja perusahaan perbankan}

Pada hipotesis keempat penelitian ini berhasil membuktikan bahwa intellectual capital sebagai mediasi hubungan antara corporate social responsibility terhadap kinerja perusahaan perbankan dengan P-values 0,000. Hal tersebut bermakna bahwa kegiatan pengawasan atau moditoring dapat mengawasi aktivitas via internal secara menyeluruh, karena kegiatan moditoring tersebut bisa dilakukan secara terencana dan berkelanjutan maka masih ada informasi-informasi yang dapat diperoleh oleh pihak eksternal oleh karena itu corporate social responsibility berpengaruh terhadap jumlah intellectual capital ataupun kinerja perusahaan perbankan.

\section{Kesimpulan}

Penelitian ini berhasil membuktikan secara empiris bahwa intellectual capital sebagai variabel mediasi hubungan antara cterhadap kinerja perusahaan perbankan terbukti berpengaruh signifikan. Hal ini bermakna bahwa semakin tinggi corporate social responsibility yang diperkuat dengan pengungkapan intellectual capital akan lebih meningkatkan kinerja perusahaan khusus perusahaan perbankan di Indonesia.

\section{Daftar Pustaka}

[1] Ali, Masyhud. (2006). Manajemen Risiko: Strategi Perbankan dan Dunia Usaha Menghadapi Tantangan Globalisasi Bisnis. PT. RajaGrafindo Persada. Jakarta

[2] Mawardi, Wisnu. (2005). Analisa Faktor Faktor yang Mempengaruhi Kinerja Keuangan Bank Umum di Indonesia (Studi Kasus pada Bank Umum dengan Total Asset Kurang dari 1 Triliun)", Jurnal Bisnis Strategi, Vol.14, No.1, pp.83-94

[3] Sholihah, I. M., \& Nuraina, E. (2013). Pengaruh Corporate Social Responsibility Indeks terhadap Kinerja Perusahaan (studi pada perusahaan infrasruktur, utilitas, dan transportasi yang listing di Bursa Efek Indonesia. Jurnal Akuntansi dan Pendidikan, Volume 2, Nomor 2, pp.71-85.

[4] Candrayanthi, A.A. Alit. \& Saputra, I.D.G. Dharma. 2013. Pengaruh Pengungkapan Corporate Social Responsibility Terhadap Kinerja Perusahaan (Studi Empiris pada Perusahaan Pertambangan di Bursa Efek Indonesia). E-Jurnal Akuntansi Universitas Udayana 4.1, pp.141-158.

[5] Pramana, I. A., \& Yadnyana, I. K. (2016). Penagaruh Corporate Social Responsibility pada Kinerja Perusahaan Manufaktur. E-Jurnal Akuntansi Universitas Udayana, Vol. 16, No.3, pp.1965-1988

[6] Cahyono, B., \& Yuyetta, E. N. (2014). Pengaruh Corporate Social Responsibility terhadap Kinerja Perusahaan dengan Kepemilikan Asing sebagai variabel Moderating (studi empiris pada perusahaan manufaktur yang terdaftar di BEI), (Doctoral Dissertation), Universitas Diponegoro.

[7] Devie, Marchyta, N. K., \& Semuel, H. (2015). Pengaruh Corporate Social Responsibility terhadap Financial Performance dengan Intellectual Capital dan Bankruption Risk sebagai variabel mediasi. Universitas Kristen Petra

[8] Machmuddah, Z., Oktafiyani, M., \& Titasari, K. H. (2018). Corporate Social Responsibility dan Corporate Financial Performance: Intellectual Capital sebagai variabel mediasi. Jurnal Riset Akuntansi, Vol. 08, No. 1, pp.1-9

[9] Daud, R. M., \& Amri, A. (2008). Pengaruh Intellectual Capital dan Corporate Social Responsibility terhadap Kinerja Perusahaan (studi empiris pada perusahaan manufaktur di BEI). Jurnal Telaah dan Riset Akuntansi, Vol. 1, No. 2, pp.213-231

[10] Santosa, S. (2012). Pengaruh Modal Intellectual dan Pengungkapannya terhadap Kinerja Perusahaan. Jurnal Akuntansi dan Keuangan, Vol. 14, No. 1, pp.16-31

[11] Kartikasari, Y., \& Hadiprajitno, P. B. (2014). Pengaruh Modal Intelectual Capital terhadap Kinerja Perusahaan (studi pada perusahaan Perbankan yang terdaftar di BEI tahun (2009-2011). Diponegoro Journal of Accounting, Vol. 3, No. 1, pp. 241-255.

[12] Sirojuddin, G. A., \& Nazaruddin, I. (2014). Pengaruh Modal Intellectual Capital dan Pengungkapan terhadap Nilai dan Kinerja Perusahaan. Jurnal Akuntansi dan Investasi, Vol. 15 No. 2, pp.77-89. 
[13] Pratama, Y. H. \& Achmad, T. (2015). Pengaruh Intellectual Capital terhadap Kinerja Perusahaan dengan Competitive Advantage sebagai variabel Intervening (Studi Pada Perusahaan Perbankan yang Terdaftar di BEI 2009-2013)," Diponegoro Journal of Accounting, vol. 4, no. 2, pp. 963-974

[14] Kuryanto, B., \& Syafruddin, M. (2008). Pengaruh Modal Intellectual terhadap Kinerja Perusahaan. Universitas Diponegoro Semarang.

[15] Anggraini, F. Ali, Abdul Hamid, M, dan Aza Azlina. (2018a). The Role of Intellectual Capital on Public Universities Performance in Indonesia. Pertanika Journal Social Science and Humanities. Vol. 26, No. 4, pp.2453-2472

[16] Anggraini, F. Ali, Abdul Hamid, M, dan Aza Azlina. (2018b). Competitive Advaantage as Mediating Role of Intellectual Capital and University Performance: An Empirical study in Indonesia. International Journal of economics and Management 12 (S2), pp.351-363.

[17] Dewi, R. K. \& Widagdo, B. (2012). Pengaruh Corporate Social Responsibility dan Good Corporate Governance Terhadap Kinerja Perusahaan. Jurnal Manajemen Bisnis, Vol.2, No.1, pp.81-97.

[18] Arianti, G. A., Yuniarta, G. A, \& Sujana, E. (2017). Pengaruh Intellectual Capital, Corporate Social Responsibility, dan Good Corporate Governance terhadap Kinerja Perusahaan (studi kasus pada perusahaan manufaktur yang terdaftar di Bursa Efek Indonesia tahun 2011-2015). e-Journal S1 Ak, Vol.7, No. 1.

[19] Saputra, W. S. (2018). Pengaruh Corporate Governance, Corporate Social Responsibility dan Intellectual Capital terhadap nilai perusahaan. National Conference of Creative Industry, Universitas Bunda Mulia. 